\title{
Diet of Iheringichthys labrosus (Pimelodidae, Siluriformes) in the Itaipu Reservoir, Paraná River, Brazil-Paraguay
}

\author{
Sara da Silva Abes, Angelo Antonio Agostinho*, Edson Kiyoshi Okada and Luiz Carlos \\ Gomes \\ NUPELIA, Universidade Estadual de Maringá, Av. Colombo, 5790 CEP 87020-900, Maringá - PR, Brazil.
}

\begin{abstract}
Iheringichthys labrosus is a secondary commercial fish species in the Itaipu Reservoir, but it is important in other reservoirs of the basin. However, little information exists about this species in the literature. The purpose of this study was to describe the diet of this species in the Itaipu Reservoir. Stomachs of 306 fishes were analyzed, collected from October 1994 to September 1996 in the differents zones of the reservoir (according to a longitudinal gradient). The reservoir was separated into riverine (upper reach), transitional (middle reach), and lacustrine (next to the dam) zones. Main items in the diet of $\mathrm{I}$. labrosus were aquatic insects (mainly Chironomidae) and mollusks (mainly Bivalvia). Their presence in the diet did not vary according to zones. Also, there was little seasonal variation in the diet. This indicated a conservative diet that could be a result of the high abundance of the items in the reservoir, or restrictions imposed by its buccal and digestive apparatus.
\end{abstract}

Key words: Itaipu Reservoir, freshwater, fish, feeding, diet composition, benthophagous

\section{INTRODUCTION}

Reservoirs are complex systems that exhibit a range of ecological, economic and social interactions (Tundisi, 1996). In ecological terms, these systems, due to human interference, show combinations of riverine and hcustrine elements. Fish species composition depends on the fauna of the rivers where they were formed (Fernando \& Holcík, 1991).

Iheringichthys labrosus is a secondary commercial fish species in the Itaipu Reservoir (FUEM/Itaipu Binacional, 1987). However, it is an important fish species in other reservoirs of the basin, especially Promissão and Água Vermelha Reservoirs (Agostinho et al., 1995; CESP, 1996). It is also an important sport fish in the sand beaches ("mandizeiros") fishery along the upper Paraná
River channel and main tributaries. With the end of the trophic upsurge period in the Itaipu Reservoir (Agostinho et al., 1999 a and b), secondary species may become important resources for the commercial fishery. I. labrosus seems to be one of these species, and it has not been well studied in the basin (Kara, 1991).

Studies on feeding of this species were conducted by Fugi (1993) and Fugi et al. (1996) in the floodplain of upper Paraná River, and characterized the species as benthophagous, feeding mainly at dawn and during daytime hours. However, there is few information on the feeding ecology of I. labrosus in the Itaipu Reservoir, in despite of its increasing importance on the commercial fishery. Thus, the purpose of this study is to analyze the diet of I. labrosus in the Itaipu Reservoir.

\footnotetext{
* Author for correspondence
} 


\section{STUDY AREA}

Itaipu Reservoir $\quad\left(24^{\circ} 05^{\prime}-25^{\circ} 33^{\prime} \mathrm{S}, \quad 54^{\circ} 00^{\prime}-\right.$ $54^{\circ} 37^{\prime} \mathrm{W}$ ) is a $1350 \mathrm{~km}^{2}$ hydropower reservoir. It was impounded in 1982 on the Paraná River along the Brazil-Paraguay border (Figure 1). The reservoir has an average depth of $21 \mathrm{~m}$ and a maximum depth of $170 \mathrm{~m}$. Retention time is about $40 \mathrm{~d}$ and discharge about $8,200 \mathrm{~m}^{3} \mathrm{~s}^{-1}$. Total phosphorus concentration averages $22 \mathrm{mg} \mathrm{m}^{-3}$ and chlorophyll a $3.6 \mathrm{mg} \mathrm{m}^{-3}$. This corresponds to trophic state indexes (Carlson, 1977) of 49 and 43, respectively, suggesting mesotrophic conditions. The reservoir is $150 \mathrm{Km}$ long and upstream is a $230 \mathrm{Km}$ long, free-flowing stretch of Paraná River. This reservoir presents a well-defined longitudinal gradient, with three different zones: riverine, transitional and lacustrine (Thornton, 1990; Agostinho et al., 1995).

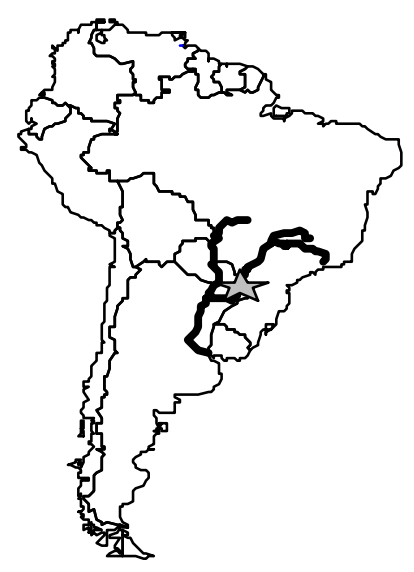

Figure 1 - Location of the Itaipu Reservoir on the Paraná River basin along the Brazil-Paraguay border.

\section{MATERIALS AND METHODS}

Fishes were collected in the differents zones of the Itaipu Reservoir from October 1994 to September 1996. Stomachs of 306 fishes (standard length: $14.3-32.9 \mathrm{~cm}$ ) were extracted and fixed in $4 \%$ formalin, then preserved in $70 \%$ alcohol. Stomach contents were identified taxonomically to the lowest possible level and expressed as \% of occurrence and \% of volume (Hynes, 1950; Hyslop, 1980). The volume of larger items was determined through displacement of water in a graduated cylinder. Small items were separated in a Petri dish, then squashed on graph paper to uniform depth of $1 \mathrm{~mm}$ to determine their volume (Hellawell \& Abel, 1971). It was assumed that $1 \mathrm{~mm}^{3}$ was equal to $0.001 \mathrm{ml}$. The results were combined into an index of food importance (IAi; Kawakami \& Vazzoler, 1980) as:

$$
\mathrm{IAi}=\frac{\mathrm{OiVi}}{\sum_{\mathrm{i}=1}^{\mathrm{i}=\mathrm{n}} \mathrm{OV}} * 100
$$

Where: $\mathrm{O}=\%$ occurrence; $\mathrm{V}=\%$ volume.

The items were grouped according to the highest taxonomic group to assess the main food resources available for I. labrosus. After the diet was described, we continued our analysis with the items that contributed at least $85 \%$ of the IAi. These items were Diptera, Trichoptera, Bivalvia, and Ostracoda. The remaining items were classified as "others". Items were classified as principal (IAi $\geq 50 \%)$, secondary $(25 \% \leq \mathrm{IAi}>$ $50 \%$ ), and accessory (IAi < 25\%) (Rosecchi \& Nouaze, 1987).

\section{RESULTS}

Food items and guild: I. labrosus was identified as benthophagous, feeding basically on benthic aquatic insects (64.7\%), and mollusks (26.1\%) (Figure 2A). The most common group of insects was immature forms of Diptera (Chironomidae). Bivalvia was the most consumed among the mollusks (Figure 2B).

The diet: The diet composition of I. labrosus in the riverine, transitional, and lacustrine zones showed few variations in the study period (Figure 3). In the riverine zone, Bivalvia predominated in the diet in 1995, and Diptera in 1996. In the transitional zone, Diptera dominated during the study period. Both Diptera and Bivalvia were abundant in the diet in the lacustrine zone, except in 1996, when Diptera predominated as principal prey.

Seasonal variations in the diet of I. labrosus were not accentuated during the study period (Figure 4). Benthic organisms can present variations related mainly to their biological cycles in the different zones of the reservoir. Diptera predominated in the diet in the spring and summer in 1994. Bivalvia was the most consumed food in the fall of 1995 and Diptera during summer. Diptera was the predominant food resource in 1996, except in the fall, when Bivalvia was predominant in the diet. Other items, such as crustaceans (Conchostraca) were important in the spring of 1995 , and in the summer of 1996. 


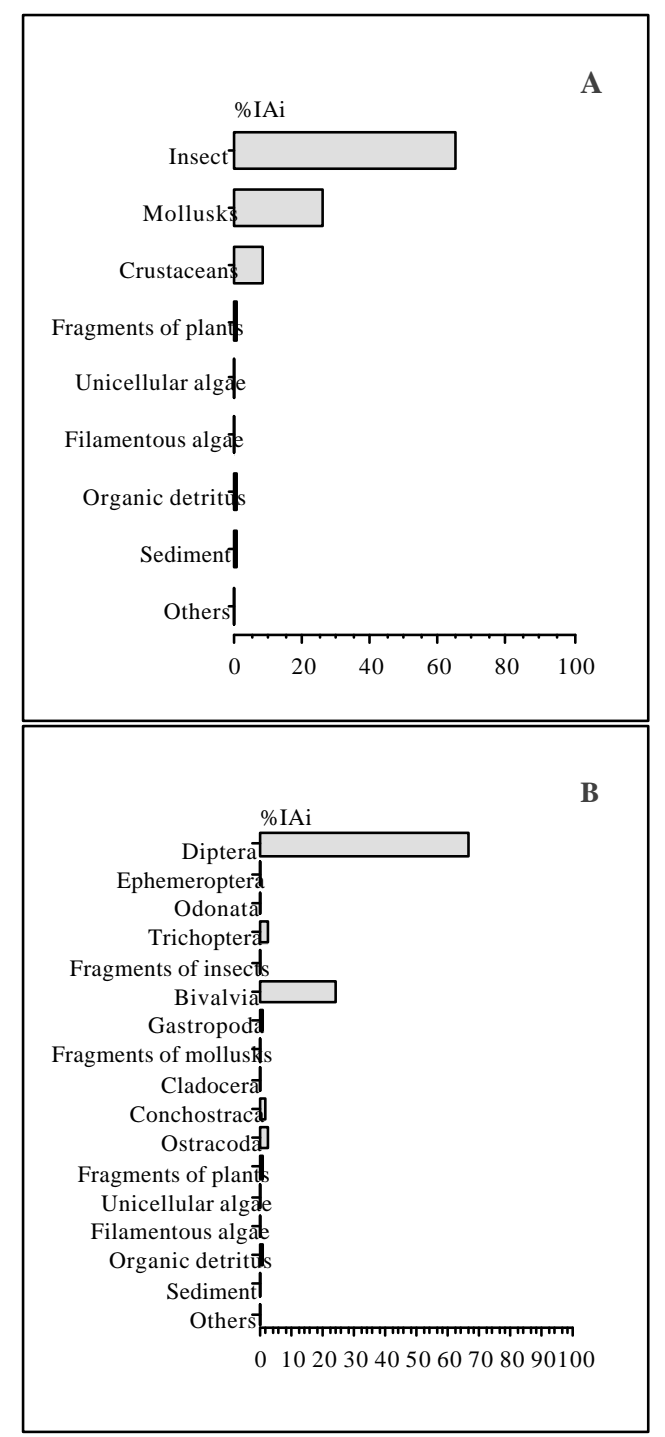

Figure 2 - Importance of the items (\%IAi) in the diet of I. labrosus in the Itaipu Reservoir (A-Food items grouped; B-Food items not grouped).

\section{DISCUSSION}

Iheringychthys labrosus is a benthophagous in the Itaipu Reservoir. This was verified by prior studies in the Itaipu Reservoir (FUEM/Itaipu Binacional, 1989), upper Paraná River basin (Fugi et al., 1996; Agostinho et al., 1997 a), Corumbá Reservoir (Agostinho et al., 1997 b), and Água Nanci Stream (Abes, 1998).
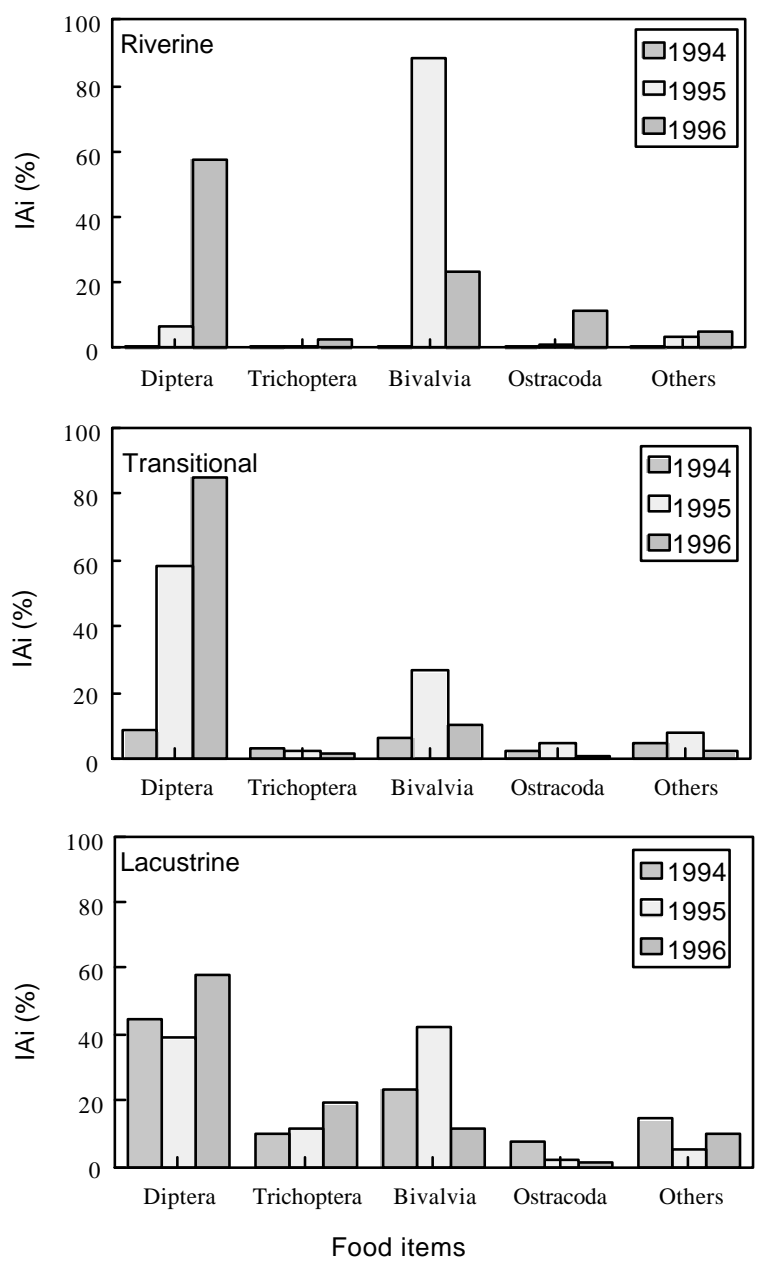

Figure 3 - Temporal (three years) and spatial (longitudinal gradient) variations in the diet of $I$. labrosus in the Itaipu Reservoir.

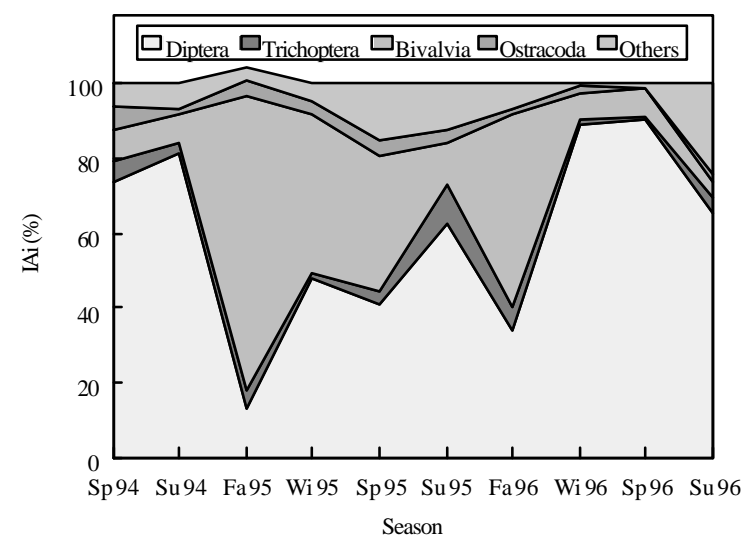

Figure 4: Seasonal variations in the food resources available for I. labrosus in the Itaipu Reservoir ( $\mathrm{Sp}$ spring; Su-summer; Fa-fall; Wi-winter; 94-1994; 951995; 96-1996).

The consistence of the diet in the different studies may result from the constraints of the buccal and digestive apparatuses. Fugi (1993) stated that the 
morphology of the digestive system allowed one to characterize the species as a selector of organisms of the meso and macro benthos. Although little amount of sediment were ingested, I. labrosus exhibited a narrow, small mouth positioned subinferiorly, with thick lips and free superior margin. Within the buccal cavity, the species was equipped with well-developed plates of teeth distributed in the premaxillary and dentary. They were also found in the pharynx. These adaptations of the buccal apparatus has function of select preys on the bottom. The short distance among gill rakers indicated that food selection might occur. Similar morphology adaptations of benthic fishes were noted by Hynes (1970), Liem (1979) and Gerking (1994). The stomach was saclike, functioning for digestive purposes.

The huge amounts of chironomids in the diet of $I$. labrosus might reflect the abundance of this group in the reservoir. After 12 years of impoundment, the benthic community seemed to be well developed. Likely, this was a result of the great quantities of vegetation that were submerged during the filling phase, which created substrate for their development (Ploskey, 1985). Also, chironomids might be considered r-strategists, with high fecundity and haemoglobin to live in low concentrations of oxygen (Baxter, 1977). This indicated great potential for the colonization of aquatic systems.

I. labrosus had a well defined diet with no relevant variation along the year. Other studies identified some differences in the proportion of food items according to the zones of the reservoir and season of year (Fugi, 1993).

In tropical streams, the abundance of the benthic invertebrates varied among streams, habitats, and season (Angermeier \& Karr, 1983). The relative abundance of drifting taxa and benthic invertebrates also showed variation among seasons in a temperate stream (Angermeier, 1982). However, other benthophagous species (callichthyids) showed little differences in the diet (aquatic insects and detritus) among seasons (Mol, 1995). This might be a result of the ample amounts of available benthic invertebrates. Hahn et al. (1991) and Fugi (1993) found similar results for another benthophagous species, Trachydoras paraguayensis, in the Itaipu Reservoir and floodplain of the upper Paraná River basin.

In conclusion, I. labrosus fed on a wide variety of aquatic invertebrates but all were benthic. This could be a result of food item abundance, or intake constraints due to the morphology of buccal and digestive apparatuses.

\section{ACKNOWLEDGEMENTS}

The authors thank NUPELIA (Maringá State University, Paraná State, Brazil), Itaipu Binacional and $\mathrm{CNPq}$ for their support, as well as Chad R. Dolan (Mississippi State University, USA) for his revision on the English manuscript.

\section{RESUMO}

Iheringychthys labrosus é uma espécie de importância secundária na pesca comercial realizada no reservatório de Itaipu, mas é importante em outros reservatórios localizados à montante. $\mathrm{O}$ objetivo desse trabalho foi descrever a dieta de I. labrosus no reservatório de Itaipu. Os conteúdos gástricos de 306 peixes foram analisados, coletados de outubro de 1994 a setembro de 1996, nas diferentes zonas do gradiente longitudinal do reservatório (fluvial, transição e lacustre). Os itens principais na dieta de I. labrosus foram os insetos aquáticos (Chironomidae) e moluscos (Bivalvia) e a dominância desses itens variou pouco durante o período estudado. Isso pode ser atribuído à elevada abundância dos itens preferenciais nas diferentes zonas, ou de restrições alimentares impostas pelas adaptações apresentadas na boca e aparelho digestório de I. labrosus.

\section{REFERENCES}

Abes, S. S. (1998), Padrões espaço-temporais na composição específica e estrutura trófica da taxocenose de peixes do riacho Água Nanci, bacia do alto rio Paraná. Master Thesis, Maringá State University, Paraná State, Brazil.

Agostinho, A. A.; Vazzoler, A. E. A. M. \& Thomaz, S. M. (1995), The high River Paraná Basin: limnological and ichthyological aspects. InLimnology in Brazil, ed. Tundisi, J.G.; Bicudo, C. E. M.; Matsumura-Tundisi, T. ABC/SBL, Rio de Janeiro, São Paulo. pp. 59-103.

Agostinho, A. A.; Hahn, N. S.; Gomes, L. C. \& Bini, L. M. (1997 a), Estrutura trófica. In-A Planície de Inundação do Alto Rio Paraná: aspectos físicos, biológicos e socioeconômicos, ed. Vazzoler, A. E. A. M.; Agostinho, A. A.; Hahn, N. S. Editora da Universidade Estadual de Maringá, Maringá, Paraná, pp. 229-248. 
Agostinho, A. A.; Vazzoler, A. E. A. M.; Pavanelli, C. S.; Abujanra, F.; Suzuki, H. I.; Júlio Jr, H. F.; Latini, J. D.; Luz, K. D. G; Bini, L. M.; Hahn, N. S.; Fugi, R.; Veríssimo, S. \& Almeida, V. L. L. (1997 b), Estudos ictiológicos na área de influência do AHE Corumbá-Fase Rio. Relatório Parcial, Universidade Estadual de Maringá, Maringá, Paraná, 289p.

Agostinho, A. A.; Miranda, L. E.; Bini, L. M.; Gomes, L. C.; Thomaz, S. M. \& Suzuki, H. I. (1999 a), Patterns of colonization in neotropical reservoirs, and prognosis on aging. In-Theoretical Limnology and its Application, ed. Straškraba, M.; Tundisi, J. G. Kluwer Academic Publishers, Dordrecht, The Netherlands, pp. 227-265.

Agostinho, A. A.; Okada, E. K. \& Gregoris, J. (1999 b), A pesca no reservatório de Itaipu: aspectos sócio econômicos e impactos do represamento. InEcologia de Reservatórios: estrutura, função e aspectos sociais, ed. R. Henry. Instituto de Biociências, UNESP, Botucatu, São Paulo, pp. 281319.

Angermeier, P. L. (1982), Resource seasonality and fish diets in an Illinois stream. Environ. Biol. Fishes, 7(3), 251-264.

Angermeier, P. L. \& Karr, J. R. (1983), Fish communities along environmental gradients in a system of tropical streams. Environ. Biol. Fishes, 9(2), 117-135.

Baxter, R. M. (1977), Environmental effects of dams and impoundments. Annu. Rev. Ecol. Syst., 8, 255283.

Carlson, R. E. (1977), A trophic state index for lakes. Limnol. and Oceanogr., 22, 361-369.

CESP (Companhia Energética de São Paulo) (1996), Aspectos limnológicos, ictiológicos e pesqueiros de reservatórios da CESP no período de 1986 a 1994. CESP (Série Pesquisa e Desenvolvimento, São Paulo, 136, 81p.

Fernando, C. H. \& Holcík, J. (1991), Fish in reservoirs. Int. Rev. Gesamten Hydrobiol., 76(2), 149-167.

FUEM (Fundação Universidade Estadual de Maringá)/Itaipu Binacional (1987), Ictiofauna e biologia pesqueira. Relatório Anual, Universidade Estadual de Maringá, Maringá, Paraná, 2, 638p.

FUEM (Fundação Universidade Estadual de Maringá)/Itaipu Binacional (1989), Ecologia de populações de peixes no reservatório de Itaipu, nos primeiros anos de sua formação. Relatório Anual, Universidade Estadual de Maringá, Maringá, Paraná, $1,152 \mathrm{p}$.

Fugi, R. (1993), Estratégias alimentares utilizadas por cinco espécies de peixes comedoras de fundo do alto rio Paraná/PR-MS. Master Thesis, São Carlos Federal University, São Paulo State, Brazil.

Fugi, R.; Hahn, N. S. \& Agostinho, A. A. (1996), Feeding styles of five species of bottom-feeding fishes of the high Paraná river. Environ. Biol. Fishes, 46, 297-307.
Gerking, S. D. (1994), Feeding Ecology of Fish. Academic Press, California, 416p.

Hahn, N. S.; Fugi, R. \& Andrian, I. F. (1991), Espectro e atividade alimentares do armadinho, Trachydoras paraguayensis (Doradidae, Siluriformes) em distintos ambientes do rio Paraná. Revista UNIMAR (Paraná), 13(2), 178-194.

Hellawell, J. M. \& Abel, R. (1971), A rapid volumetric method for the analysis of the food of fishes. J. Fish Biol., 3, 29-37.

Hynes, H. B. N. (1950), The food of freshwater sticklebacks (Gasterosteus aculeatus and Pygosteus pungitius), with a review of methods used in studies of the food of fishes. J. Anim. Ecol., 19(1), 36-58.

Hynes, H. B. N. (1970), The Ecology of Running Waters. Liverpool University Press, Liverpool, 555p.

Hyslop, E. J. (1980), Stomach contents analysis a review of methods and their application. J. Fish Biol., 17, 411-429.

Kara, S. (1991), Morfologia ovariana e reprodução dos mandis Iheringichthys labrosus e Pimelodus maculatus (Siluriformes, Pimelodidae) em duas represas da bacia do Paraná Superior. Master Thesis, Minas Gerais Federal University, Minas Gerais State, Brazil.

Kawakami, E. \& Vazzoler, G. (1980), Método gráfico e estimativa de índice alimentar aplicado no estudo de alimentação de peixes. Bol. Inst. Oceanogr., 29(2), 205-207.

Liem, K. F. (1979), Modulatory multiplicity in the feeding mechanism in cichlid fishes, as exemplified by the invertebrate pickers of Lake Tanganyika. $J$. Zool., 189, 93-125.

Mol, J. H. (1995), Ontogenetic diet shifts and diet overlap among three closely related neotropical armoured catfishes. J. Fish Biol., 47, 788-807.

Ploskey, G. R. (1985), Impacts of terrestrial vegetation and preimpoundment clearing on reservoir ecology and fisheries in the USA and Canada. FAO Fish. Tech. Pap., 285, 35p.

Rosecchi, E. \& Nouaze, Y. (1987), Comparaison de cinq indices alimentaires utilisés dans l'analyse des contenus stomacaux. Rev. Trav. I'Inst. Peches Marit., 49, 111-123.

Thornton, K. W. (1990), Perspectives in reservoir limnology. In-Reservoir Limnology: ecological perspectives, ed. Thornton, K. W.; Kimmel, B. L.; Payne, F. E. Wiley, New York, pp. 1-13.

Tundisi, J. G. (1996), Reservoirs as complex systems. Ciênc. Cult. (São Paulo), 48(5/6), 383-387.

Received: September 24, 1999; Revised: July 31, 2000; Accepted: August 16, 2000. 